\title{
Vinski turizem
}

\author{
Simon Kerma \\ UP Fakulteta za turistične študije - Turistica \\ simon.kerma@fts.upr.si \\ Aleš Gačnik \\ UP Fakulteta za turistične študije - Turistica \\ ales.gacnik@fts.upr.si
}

\section{Fenomen vinskega turizma in njegove opredelitve}

Nekoliko posplošen pristranski pogled (zlasti popotniških ljubiteljev vina) nepoučene napeljuje $\mathrm{k}$ prepričanju, da sta vino in turizem vseskozi neizogibno povezana; a temu ni tako. O prvih zametkih vinsko motiviranih (organiziranih) potovanj resda lahko govorimo že od srede 19. stoletja dalje, kar je povezano z razvojem železnic in predvsem s krepitvijo ekonomske moči srednjega razreda, ki se v mnogočem ozira po statusnih simbolih plemstva in posledično vse bolj povprašuje po vrhunskih vinih iz prestižnih vinskih regij. A vino oz. vinorodne dežele kot središčni element turistične izkušnje so prejkone sodobni fenomen z manj kot polstoletno tradicijo. Sistematičnim začetkom razvoja vinskega turizma lahko sledimo predvsem $\mathrm{v}$ deželah t. i. "Novega sveta«, kjer je ob vinsko-vinogradniški pridelavi turizem zelo hitro postal sestavni del vinskega posla. Primerjalno je prav v tem tudi bistvena razlika glede na razvoj vinskega turizma v Evropi oz. v t. i. »Starem svetu«, ki se šele dobri dve desetletji in- 
tenzivneje usmerja $\mathrm{v}$ povezovanje vinogradništva in vinarstva $\mathrm{s}$ turistično ponudbo (in širše s kulturo vina). Podobne analogije lahko prepoznavamo tudi na področju raziskovanja vinskega turizma, kar podrobneje analizira Charters (2009; 2012).

Zametke akademskega zanimanja za preučevanje vinskega turizma lahko časovno umestimo $\mathrm{v}$ drugo polovico devetdesetih let prejšnjega stoletja, a naj na tem mestu izpostavimo tri temeljna dela, ki so začrtala smernice raziskav na tem področju: Explore Wine Tourism: Management, Development \& Destinations (Getz, 2000) in Wine Tourism around the World (Hall idr., 200o) sta pionirski znanstveni monografiji s preloma tisočletja, kjer so avtorji sistematično uredili dotedanje parcialne študije in sprožili val povečanega zanimanja za raziskave, ki postanejo na eni strani bolj specializirane, a hkrati tudi eklektične, in ki se razvijejo od konceptualnejših študij primera $\mathrm{v}$ vsestransko in obsežno preučevanje fenomena vinskega turizma. To se v dobršni meri odrazi v tretjem temeljnem delu z naslovom Global Wine Tourism: Research, Management and Marketing (Carlsen in Charters, 2006). Slednje premošča razkorak med teoretskimi in bolj aplikativnimi rezultati raziskovanj. Opazen je premik od deskriptivnih študij primera do ugotavljanja povezav med vinskim turizmom in trajnostnim regionalnim razvojem, politiko in načrtovanjem rabe tal, marketingom in demografskimi izzivi vinskega turizma ter vedênjem in izkustvenim doživljanjem vinskih turistov (Kerma, 2018).

Carlsen in Charters sta s pomočjo skupine sodelujočih avtorjev definirala polje raziskav s področja vinskega turizma praktično vse do danes, pri čemer lahko pri razumevanju in razvoju vinskega turizma še vedno izpostavimo različne pristope med vinskimi regijami Starega (Mediteran, Evropa) in Novega sveta (Avstralija, Nova Zelandija, Južna Afrika, Južna Amerika, Kanada in zDA). Urednika monografije sta v uvodnem poglavju predstavila tudi rezultate kvalitativne analize znanstvene turistične literature s področja vinskega turizma iz baze CIRET $^{1}$ in na tej podlagi sistematizirala pet tematskih raziskovalnih sklopov (Carlsen in Charters, 2006, str. 5):

1. kultura in dediščina v vinskem turizmu,

2. podjetništvo $\mathrm{v}$ vinskem turizmu,

3. marketing $\mathrm{v}$ vinskem turizmu,

1. Centre International de Recherces et d'Etudes Turistiques (http://www.cirettourism.com). 


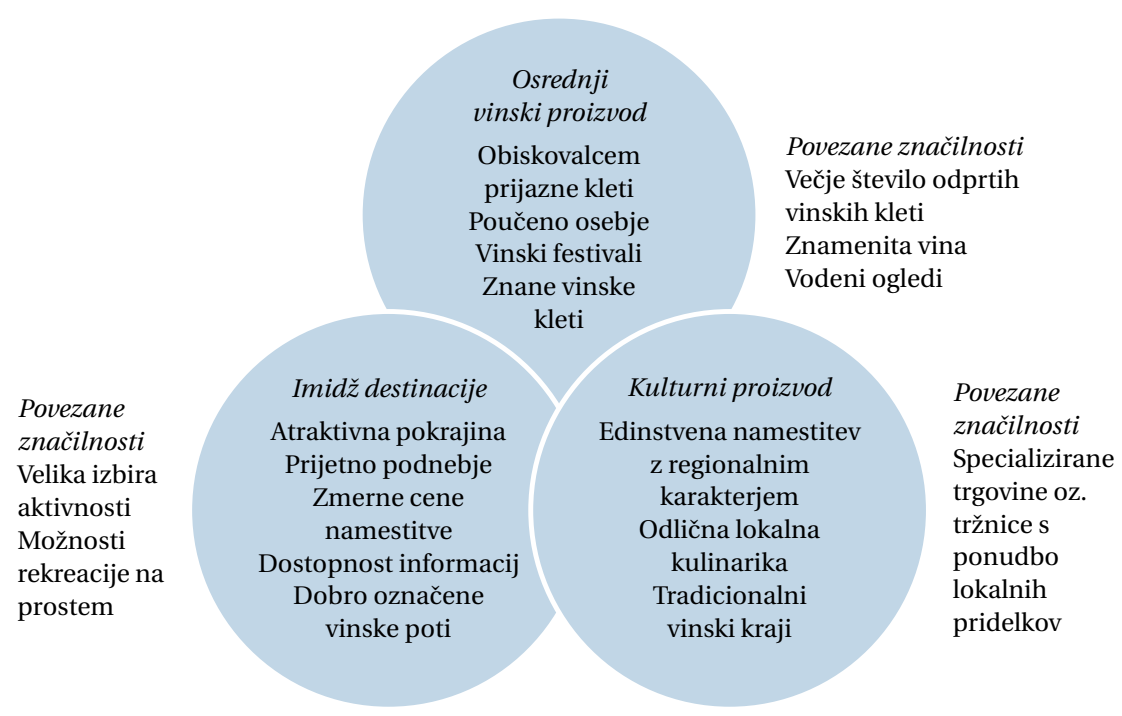

Slika 5.1 Ključni dejavniki uspešnega razvoja vinskoturistične destinacije (prirejeno po Getz in Brown, 2006, str. 156)

4. vedênje vinskih turistov,

5. vinskoturistični sistemi.

Pri opredelitvi vinskega turizma se večina avtorjev sklicuje na eno prvih definicij, kjer se izpostavlja »obisk vinogradov, vinarjev, vinskih festivalov in drugih tovrstnih prireditev, pri čemer kot glavni motiv obiskovalcev nastopa degustacija vina in/ali doživljanje posebnosti vinske regije« (Hall in Macionis, 1998 v Hall idr., 2000, str. 3).

Pomembno dopolnitev predstavlja identifikacija ključnih dejavnikov za uspešen razvoj vinskoturistične destinacije (Getz in Brown, 2006) (slika 5.1), pri čemer se vinski turizem obravnava simultano; kot obliko vedênja potrošnika, kot strategijo, s katero turistične destinacije oblikujejo lokalni razvoj in tržijo lokalna vina, in kot marketinško priložnost za vinarje, ki lahko tako svoje proizvode prodajo neposredno kupcu. Zelo podobna kritična izhodišča ali možne pristope, ki se medsebojno prepletajo oz. dopolnjujejo in so torej enako pomembni pri vzpostavitvi pogojev za razvoj vinskega turizma, izpostavljajo tudi Wade idr. (2006).

Različnih izpeljank osnovne definicije je še precej več. V širšem (produktnem in holističnem) smislu lahko vinski turizem skupaj s kulinaričnim umestimo v polje kulturnega turizma. Obe vrsti turiz- 
ma specifičnih ciljnih skupin sta praviloma precej povezani in komplementarni. V praksi poznamo tudi posebne oblike vinskega turizma, kot so npr. vinske prireditve, katerih znana prizorišča so največkrat v večjih mestih oz. urbanih okoljih in celo izven vinorodnih območij (npr. London, Ljubljana). Bistven je torej kontekst, geografske, ekonomske in kulturne specifike, ki določajo značilnosti oz. identiteto posamične vinskoturistične destinacije (Kerma, 2014).

Podobno razmišlja tudi Gačnik, ki vinski turizem opredeljuje kot posebno zvrst gastronomskega ali kulturnega turizma, kjer je potovanje usmerjeno $\mathrm{k}$ holističnemu doživetju kulture vina, tako v ruralnih kot urbanih okoljih, z namenom prodaje vina skozi avtentične ali sodobne vinske zgodbe, zavoljo celostnega doživetja vinskoturističnih identitet in destinacij kot kulturološkega terroirja. Vinski turizem je po Gačniku (2014a) kreativni in inovativni medij za komuniciranje vina, vinogradnikov in vinarjev, dediščine in kulture vina ter vinoloških posebnosti vinorodnih regij in držav.

Vinski turizem predpostavlja zasnovo kompleksnega sistema, ki zahteva med drugim tudi razvito lokalno infrastrukturo (npr. vinskoturistične ceste), zlasti pa je ta dejavnost zahtevna na ravni posamičnih ponudnikov (vinskih kleti), saj predvideva precejšnje investicije, turistične in gostinske spretnosti, predvsem pa željo in voljo vinarjev, da postanejo del sistema vinskega turizma (Bojnec idr., 2007). Kot uporabne indikatorje za oceno razvitosti vinskega turizma se lahko upošteva: število vinskih kleti, število zaposlenih v vinskem turizmu, število in raznovrstnost specializiranih turističnih proizvodov, ki se povezujejo s ponudbo vinskega turizma (npr. kulturni turizem, ekoturizem ipd.), pomembnost prodaje in izvoza vina za vinske kleti, uporabo marketinških komunikacijskih orodij in promocijskih metod za obisk vinskih kleti, rast prihodkov od vinskega turizma, povezanost vinogradnikov in vinarjev (vinska združenja, konzorciji) (Jurinčič in Bojnec, 2009, str. 473-474).

\section{Profil vinskih turistov}

Vedenjske, socio-ekonomske in demografske raziskave, ki so povezane s prepoznavanjem profila vinskih turistov, z njihovimi pričakovanji, potrebami, vrednotami, izkušnjami, motivacijami (Ross, 1994; Hall in Macionis, 1998; Hall idr., 2000; Bojnec in Korpar, 2005; Carlsen in Charters, 2006; Byrd idr., 2016; Quadri-Felitti in Fiore, 2016; Gačnik, 2016; Vo Thanh in Kirova, 2018), sodijo med pet glavnih te- 
matskih sklopov, s katerimi so se raziskovalci ukvarjali na področju raziskovanja vinskega turizma (Carlsen in Charters, 2006), z namenom, da bi lahko vinsko turistična industrija lažje tržila turistične proizvode (Hall idr., 2000, str. 125-126). Večina tovrstnih raziskav prihaja iz t. i. novega vinskega sveta (Avstralija, Kanada, Nova Zelandija, Južna Afrika, Južna Amerika, zDA, Kitajska ...), kjer je vinski turizem sestavni in neločljivi del vinske industrije. $V$ zadnjih desetih letih so tovrstne raziskave vse pomembnejša in vse pogostejša tema raziskovanja tudi v vinorodni Evropi.

Hall in Macionis (1998) sta opredelila tri segmente vinskih turistov in njihove glavne značilnosti. Mednje sodijo ljubitelji vina, zainteresirani za vino in radovedni turisti. $V$ znanstveni in strokovni literaturi se najpogosteje navajajo štirje tipi vinskih turistov (Hall idr., 200o):

1. »Strokovnjak» (angl. professional): star 30-45 let, poznavalec vina, sposoben presojati kakovost vina in razpravljati o vseh vidikih vina tudi z izkušenimi vinarji. Vedno ga zanimajo novosti, ki jim je pripravljen posvetiti precej energije, časa in denarja.

2. "Strasten začetnik« (angl. impassioned neophyte): star 25-30 let, rad ima vino, vendar o njem malo ve, je radoveden in željan eksperimentiranja. S pomočjo vina vzpostavlja nove prijateljske stike, uživa v hrani in raziskovanju podeželja. Običajno potuje s prijatelji, s seboj ima vodnike, brošure in zemljevide. Rad bi se poučil o vinu, a ne na strokovni ravni.

3. "Pristaš« (angl. the hanger-on): star 40-6o let, premožen, vino ga privlači, ker je zanj znanje o njem znak družbenega razlikovanja. Ima osnovno znanje o vinu, posega predvsem po vrhunskih vinih, zanj pa je pomemben tudi videz vinskih kleti. Dodali bi lahko tudi etiketo vina.

4. »Pivec« (angl. the drinker): star 50-6o let, vinske kleti obiskuje v skupini, predvsem ob nedeljah, pije in kupuje večje količine vina.

Profil vinskih turistov bi lahko prepoznali tudi v kontekstu gastronomskega turizma na Slovenskem, in sicer v segmentaciji gastronomskih turistov na naključne (zeleni raziskovalci), zainteresirane (aktivni nostalgiki, sproščeni eskapisti) in predane gastronomske turiste (družabni foodieji) (Slovenska turistična organizacija, 2018, str. $31)$.

Lapsley in Moulton (2001) pri vinskih turistih prepoznavata tudi 
zunanje in notranje motivacijske dejavnike. Pri zunanjih je to identiteta vinorodne regije $\mathrm{z}$ vsemi značilnostmi in aktivnostmi, ki se ponujajo (ogledi vinskih kleti, degustacije, nakupovanje vina itn.). Med notranjimi dejavniki se izpostavlja druženje, spoznavanje vina, osebno interakcijo med vinskim turistom in vinarjem, s čimer se izboljšuje in krepi znanje o vinogradništvu, vinarstvu, vinu. Osebni stiki z vinarji med vinskimi turisti sprožajo povečano zaupanje v vinarja in njegova vina ...

Vinski turisti želijo spoznati vinorodne pokrajine, dobro ohranjeno naravo ter lokalne prebivalce. Za posamezne vinske turiste je lahko razlog za obisk vinske kleti le želja po nakupu določenega vina, vendar želijo pravi vinski turisti o vinu izvedeti čim več (Bojnec in Korpar 2005, str. 196). In kdo je vinski turist? Če nekoliko posplošimo, bi raziskovalna spoznanja različnih avtorjev lahko strnili v naslednje značilnosti: je reden porabnik vina, starostnega razpona med 30-50 let, moški in ženska, višje in visoke izobrazbe, s srednje visokimi in visokimi prihodki, z večjim socialnim in kulturnim kapitalom, prihaja pretežno iz vinorodnih regij.

\section{Vinska regija, terroir in razvoj vinskoturistične destinacije}

Vinsko regijo bi poenostavljeno lahko definirali kot neko konkretno vinorodno območje, kjer uspeva vinska trta. Nekoliko kompleksnejše razumevanje izpostavlja identitetni vidik regije, ki poleg njenih značilnih elementov vključuje tudi marketinško komponento. Po Bruwerju (cit. v Johnson in Bruwer, 2007) je namreč imidž (blagovna znamka) vinske regije povezan s percepcijo oz. prepričanjem o določeni zaokroženi vinski pokrajini (angl. winescape), ki je navadno celostni in večdimenzionalni prostor z notranje povezanimi naravnimi in družbeno-kulturnimi sestavinami. Pri vinski regiji se tako medsebojno prepletajo naslednji vinskopokrajinski elementi (Johnson in Bruwer, 2007, str. 277):

- vinogradi,

- vinske kleti in druga infrastruktura,

- vina,

- naravna pokrajina,

- lokalno prebivalstvo in obiskovalci,

- kulturna dediščina (mesta, zgradbe, arhitektura, posebni artefakti itd.). 
Identiteta vinske regije oz. njen terroir sta ključna pri oblikovanju in načrtovanju (samo) promocije vinske regije, ki se najočitneje izraža v predstavitvi značilnosti njenega osrednjega proizvoda (pridel$\mathrm{ka}$ ), to je vina. Remaud in Lockshin (2009) izpostavljata potencialno težišče promocijskih aktivnosti, ki vključuje poudarjanje tipičnih sort grozdja in s tem geografskega porekla oz. imena vinske regije. Menita, da bi bilo v kontekstu razvoja vinskega turizma ključno evidentirati in poudariti tiste vinske ter turistične atrakcije, ki bi delovale kot sredstvo za dvigovanje regionalne zavesti (Remaud in Lockshin, 2009, str. 80). Izbor ustreznih strategij in politik institucionalizacije vinskih regij je torej ključen vidik načrtovanja, usmerjanja in razvoja vinskega turizma.

Na tem mestu je primerno pojasniti vlogo koncepta terroir. Gre za pojem, ki se zaradi svoje večpomenskosti izmika natančnemu prevodu in kot tak raje ostaja v originalnem zapisu, tako pri rabi v slovenščini kot tudi v drugih tujih jezikih. $V$ francoskem izvirniku ima kar tri splošne pomene, in sicer: (a) teritorij oz. regija, (b) manjše zemljišče, domnevno zelo kakovostno oz. kmetijsko primerno, (c) (figurativno opredeljen kot) podeželsko in provincialno območje, kjer najdemo prav posebne domačine značilnega karakterja in duha (Vaudour, 2002). Pomeni, s katerimi skuša avtorica opisati bistvo terroirja, so: edinstvenost, poreklo, specifičnost in osebnost oz. značajnost. Ti opisi vključujejo različne vidike, iz katerih izhajajo štirje tipi terroirja (Vaudour, 2002, str. 119-120):

- hranilni, gojitveni (angl. nutriment, plant-growing) terroir,

- teritorialni, prostorski (angl. territory, space) terroir,

- identitetni, zavestni (angl. identity, conscience) terroir in

- promocijski, oglaševalski (angl. advertising, slogan) terroir.

Terroir je svojo razumljivo in pomembno vlogo našel v kontekstu zaščite vin oz. določanja njihovega geografskega porekla. Terroir operira s prepričanjem, da vsako vino vsebuje značilnosti določenega okolja, v katerem dozoreva grozdje. Pri tem so poleg fizičnih dejavnikov pomembni tudi kulturni vidiki. Pri razumevanju terroirja je torej geografija tista, ki vinu osmisli prostor ali izkustvo kraja (angl. sense of place) in ga dela posebnega oz. drugačnega od vin, ki so pridelana drugje. Aplikativnost terroirja se tako kaže v bolj ali manj zavezujočih sistemih pravil, ki definirajo kontrolo geografskega porekla po posameznih državah, vinskih regijah oz. okoliših (Kerma, 
2018, str. 162). Konceptualizacija in razvoj vinskoturistične destinacije (regije) predpostavlja vzajemno prepletanje dveh vidikov. Na eni strani lahko obstoječa (ali potencialna) turistična destinacija osmišlja in nadgrajuje svoj obstoj v povezavi z vinom, obratno pa lahko vinarji svoje vinske kleti vzpostavljajo ali nadgrajujejo kot turistične atrakcije. Na neki kritični točki dovolj intenzivnega vključevanja lahko to $\mathrm{v}$ širšem kontekstu postane pomembna sestavina konkretne vinske regije oz. turistične destinacije.

Na osnovi Butlerjevega modela življenjskega cikla turistične destinacije (TALC) sta R. Tomljenović in Getz razvila hipotetični model, iz katerega lahko razberemo opise za štiri faze $\mathrm{v}$ življenjskem ciklu vinskoturistične destinacije: (1) začetno fazo, (2) razvojno fazo, (3) fazo zrelosti in (4) fazo upadanja (Tomljenović in Getz, 2009; preglednica 5.1). Na primeru Brd sta model istega leta testirala Jurinčič in Bojnec (2009), za Slovensko Istro pa Kerma (2018).

\section{Vinski turizem v izbranih regijah sveta}

Vzgoja vinske trte (kjer to dopuščajo naravni pogoji) in pridelava vina (ki je med drugim tudi družbeno-kulturno pogojena) sta danes razširjeni domala po vsem svetu zmernega podnebja, od najznamenitejših francoskih vinogradniških leg do uveljavljenih vinskih kleti Novega sveta na južni polobli ter še povsem novih in neznanih vinorodnih območij na Kitajskem. Vsaka vinska regija ima svojstvene značilnosti, ki vplivajo na okus in slog končnega pridelka. V nadaljevanju bodo predstavljene glavne značilnosti vinskega turizma v izbranih vinskih regijah Starega (Francije, Italije in Avstrije) in Novega sveta (Argentine in Čila). Nekaj besed bo namenjenih tudi Gruziji, ki si zasluži ločeno obravnavo, saj se ta posebna dežela izpod Kavkaza promovira in je tudi prepoznana kot pradomovina (zibelka) svetovnega vinogradništva in vinarstva (Kerma, 2018).

V Franciji je vinski turizem v porastu od 8o. let 20. stoletja (Hall idr., 2000). Od takrat se povečujeta število znanih vinogradov in vinskih kleti, ki se odpirajo za javnost, prav tako število vinskih cest in $s$ tem povezana turistična infrastruktura. Vinske kleti za razvoj vinskoturistične infrastrukture in privlačnosti za turiste uporabljajo dva osnovna strateška pristopa: (a) precejšnja vlaganja v vinske muzeje, raziskovalne centre, umetniške galerije in razstavne (prireditvene) prostore, vinske poti, restavracije in namestitvene obrate; (b) kreiranje neformalnih mrež vinskih združenj, konzorcijev in klubov, kate- 
Preglednica 5.1 Življenjski cikel hipotetične vinskoturistične destinacije

\begin{tabular}{|c|c|c|c|c|}
\hline Postavka & Začetek & Razvoj & Zrelost & Upad \\
\hline $\begin{array}{l}\text { Stopnja } \\
\text { razvitosti } \\
\text { vinskega } \\
\text { turizma }\end{array}$ & $\begin{array}{l}\text { V obstoječih } \\
\text { vinskih kleteh } \\
\text { ne razmišljajo } \\
\text { o turizmu; zelo } \\
\text { malo vinskih tu- } \\
\text { ristov. }\end{array}$ & $\begin{array}{l}\text { Porast števila } \\
\text { vinskih turistov; } \\
\text { nove vinske kle- } \\
\text { ti nastajajo (tu- } \\
\text { di) zaradi turiz- } \\
\text { ma, nekatere } \\
\text { kleti so že zelo } \\
\text { prepoznavne. }\end{array}$ & $\begin{array}{l}\text { Visoka stopnja } \\
\text { razvitosti vin- } \\
\text { skega turizma } \\
\text { in konkurenč- } \\
\text { nosti. }\end{array}$ & $\begin{array}{l}\text { Upad števila } \\
\text { obiskovalcev; } \\
\text { nekatere vinske } \\
\text { kleti postajajo } \\
\text { neprofitabilne, } \\
\text { ogrožen je nji- } \\
\text { hov obstoj. }\end{array}$ \\
\hline $\begin{array}{l}\text { Vrsta tu- } \\
\text { rizma }\end{array}$ & $\begin{array}{l}\text { Ni turizma oz. } \\
\text { vinski turizem } \\
\text { ne zanima ob- } \\
\text { stoječih tržnih } \\
\text { segmentov. }\end{array}$ & $\begin{array}{l}\text { Porast števila } \\
\text { turistov, ki jih } \\
\text { zanima vinski } \\
\text { turizem; zače- } \\
\text { tek masovnega } \\
\text { turizma v zna- } \\
\text { nih kleteh. }\end{array}$ & $\begin{array}{l}\text { Mešanica raz- } \\
\text { ličnih tržnih se- } \\
\text { gmentov; na- } \\
\text { petosti med tr- } \\
\text { žnimi nišami in } \\
\text { masovnim tu- } \\
\text { rizmom. }\end{array}$ & $\begin{array}{l}\text { Upad števila tu- } \\
\text { ristov, ki jih za- } \\
\text { nima vinski tu- } \\
\text { rizem; manj pri- } \\
\text { hodkov po obi- } \\
\text { skovalcu. }\end{array}$ \\
\hline $\begin{array}{l}\text { Pomen } \\
\text { vinskega } \\
\text { turizma } \\
\text { za vinske } \\
\text { kleti }\end{array}$ & $\begin{array}{l}\text { Turizem je za } \\
\text { večino vinskih } \\
\text { kleti postran- } \\
\text { ski; veliko kleti } \\
\text { sploh ni aktivno } \\
\text { vključenih. }\end{array}$ & $\begin{array}{l}\text { Mešanica } \\
\text { vinskih kle- } \\
\text { ti, usmerje- } \\
\text { nih v turizem, } \\
\text { in tistih, ki so } \\
\text { usmerjene le v } \\
\text { prodajo/izvoz } \\
\text { vina. }\end{array}$ & $\begin{array}{l}\text { Skoraj vse kle- } \\
\text { ti so vključene v } \\
\text { vinski turizem; } \\
\text { nekatere so od- } \\
\text { visne od direk- } \\
\text { tne prodaje vina } \\
\text { v kleti. }\end{array}$ & $\begin{array}{l}\text { Upad prihod- } \\
\text { kov od prodaje } \\
\text { vina v kleti kot } \\
\text { tudi drugih pri- } \\
\text { hodkov; visoka } \\
\text { stopnja odvi- } \\
\text { snosti od drugih } \\
\text { kanalov distri- } \\
\text { bucije. }\end{array}$ \\
\hline
\end{tabular}

Nadaljevanje na naslednji strani

rih skupno delo je usmerjeno $\mathrm{v}$ razvoj vinskega turizma, ter povezan nastop in promocija na turističnem trgu. Kot izjemno uspešen način komuniciranja in označevanja lahko izpostavimo Vignoble et Décuvertes, nacionalno vinskoturistično znamko oz. certifikat, ki vključuje 36 francoskih vinorodnih območij (The Vignobles \& Découvertes Label, 2020). Vinskih in vinskoturističnih presežkov v Franciji gotovo ne manjka. Naj izpostavimo Šampanjo (Champagne), katere izbrane lokacije so bile zaradi zgodovinskih vezi s pridelavo famoznega šampanjca vpisane na unESCO-v seznam svetovne kulturne dediščine. Na Unescovem seznamu je tudi Bordeaux, ki je v ekskluzivni mreži svetovnih vinskih prestolnic (www.greatwinecapitals.com) in ki se ponaša z izjemnim muzejskim kompleksom, posvečenim kulturi vina - La Cité du Vin.

Pestrost in raznolikost italijanskih pokrajin se odraža v prepoznav- 
Preglednica 5.1 Nadaljevanje s prejšnje strani

\begin{tabular}{|c|c|c|c|c|}
\hline Postavka & Začetek & Razvoj & Zrelost & Upad \\
\hline $\begin{array}{l}\text { Pomen } \\
\text { vinskega } \\
\text { turizma } \\
\text { za regijo }\end{array}$ & $\begin{array}{l}\text { Ni razumevanja } \\
\text { za pomembnost } \\
\text { vinskega turiz- } \\
\text { ma; le nekatere } \\
\text { kleti vidijo po- } \\
\text { tencial. }\end{array}$ & $\begin{array}{l}\text { Prepoznavanje } \\
\text { potenciala vin- } \\
\text { skega turizma } \\
\text { na podlagi vi- } \\
\text { dnih trendov; } \\
\text { obstoj želje po } \\
\text { razvoju vinske- } \\
\text { ga turizma. }\end{array}$ & $\begin{array}{l}\text { Odpiranje novih } \\
\text { delovnih mest } \\
\text { in opazni tudi } \\
\text { drugi ekonom- } \\
\text { ski učinki vin- } \\
\text { skega turizma, } \\
\text { ki bi lahko po- } \\
\text { stal dominan- } \\
\text { tna aktivnost. }\end{array}$ & $\begin{array}{l}\text { Upad ekonom- } \\
\text { ske pomemb- } \\
\text { nosti vinskega } \\
\text { turizma; ta se } \\
\text { lahko doživlja } \\
\text { kot regionalna } \\
\text { kriza. }\end{array}$ \\
\hline Strategije & $\begin{array}{l}\text { Spodbude in } \\
\text { pomoč podje- } \\
\text { tništvu; prite- } \\
\text { gnitev investicij; } \\
\text { oblikovanje vi- } \\
\text { zije. }\end{array}$ & $\begin{array}{l}\text { Znamčenje de- } \\
\text { stinacije vin- } \\
\text { skega turizma; } \\
\text { usmerjenost na } \\
\text { vinske turiste z } \\
\text { višjo kupno mo- } \\
\text { čjo; integrira- } \\
\text { nje vinskega tu- } \\
\text { rizma v skupno } \\
\text { politiko turistič- } \\
\text { nega razvoja. }\end{array}$ & $\begin{array}{l}\text { Trajnostna } \\
\text { usmerjenost; } \\
\text { možno zmanj- } \\
\text { šanje marketin- } \\
\text { ških aktivnosti } \\
\text { zaradi zmanjša- } \\
\text { nja množičnosti } \\
\text { obiska. }\end{array}$ & $\begin{array}{l}\text { Potrebno novo } \\
\text { pozicioniranje; } \\
\text { kreiranje novih } \\
\text { prodajnih stra- } \\
\text { tegij (s poudar- } \\
\text { kom na unika- } \\
\text { tnosti); pouda- } \\
\text { rek na kakovosti } \\
\text { vina. }\end{array}$ \\
\hline
\end{tabular}

Opombe Prirejeno po Tomljenović in Getz v Jurinčič in Bojnec (2009, str. 476-477).

nih vinskih regijah, ki ponujajo nešteto možnosti za oblikovanje vinskih cest in itinerarijev (glej npr. D’Alessio in Santini, 2006). Odlične možnosti za razvoj vinskega turizma pa so bile prepoznane relativno pozno - šele v začetku devetdesetih let prejšnjega stoletja, saj je do takrat večina vinskih kleti ignorirala turistični potencial pridelave vina in vinorodnih območij. Leta 1993 je bila zato ustanovljena posebna organizacija Movimento Turismo del Vino (Gibanje za vinski turizem), neprofitno združenje, ki danes vključuje že okrog 1.000 članov. Ti so izbrani po posebnih kriterijih, med katerimi je na prvem mestu prijaznost do vinskega turizma. Njihovi glavni cilji pa so (Kerma, 2018, str. 40):

- promocija kulture vina z obiskovanjem območij pridelave;

- podpora turizmu v vseh italijanskih regijah, ki izkazujejo vinogradniško-vinarsko poslanstvo;

- usposabljanje vinskih kleti s turističnimi znanji in storitvami;

- krepitev tako podobe (imidža) kakor tudi ekonomskih in zaposlitvenih možnosti v vinskih regijah. 
Movimento Turismo del Vino organizira številne prireditve po vsej Italiji, med katerimi je najbolj znana »Cantine Aperte« (Odprte kletivsako zadnjo nedeljo v maju), ki je postala vzorčni primer oz. model za podobne prireditve po vsem svetu - tudi pri nas.

Avstrija ima verjetno najstrožjo zakonodajo in regulacijo zaščite porekla ter kakovosti vina na svetu, ki se še posebej odraža v sistemu DAC (Districtus Austriae Controllatus) (Robinson, b.l.). Prav gotovo je to posledica velikega škandala s konca osemdesetih let prejšnjega stoletja, ko so za potrebe nemškega trga (ta je zahteval bela sladkasta vina) avstrijski vinarji v svoja vina dodajali dietilenglikol (po domače antifriz) in jih s tem krepko ponarejali. Škandal je spravil na kolena celotno vinsko industrijo, hkrati pa je pomenil nov začetek in izjemen dvig kakovosti avstrijskih vin v naslednjih dvajsetih letih (D'Alessio in Santini, 2006). Vinski turizem je z vidika promocije in trženja avstrijskih vin vedno bolj prepoznaven in cenjen, saj promovira tako nacionalno kot tudi regionalno in lokalno kulturo vina. Letno tako v Avstriji zabeležijo kar dva milijona domačih in tujih vinsko-kulinaričnih turistov, ki uživajo v raznoliki ponudbi (Kerma, 2018).

Gruzija ima nedvomno eno najstarejših in najvitalnejših vinskih kultur na svetu. In Gruzijci za svojo deželo ponosno trdijo, da je pradomovina ali zibelka vinogradništva in vinarstva. Pohvalijo se namreč s kar 8.000 neprekinjenimi trgatvami. Prav tako Gruzijci svojo vitalnost in dolgoživost pripisujejo svojemu navdušenju nad uživanjem vina. Ohranjajo tudi prav posebne tradicionalne postopke "kletarjenja" oz. pridelovanja vina, med katerimi sta gotovo najunikatnejša fermentacija in zorenje vina v kvevrijih. Postopek starodavne tradicionalne gruzijske metode pridelave vina $\mathrm{v}$ kvevrijih je bil leta 2013 uvrščen tudi na UNESCO-v seznam nesnovne dediščine sveta. Vinski turizem se tako zdi kot naročen in je v zadnjih letih dejansko tudi postal ena ključnih razvojnih usmeritev gruzijskega turizma nasploh (Kerma, 2018).

Veliki južnoameriški sosedi, Čile in Argentino, v veliki meri zaznamujejo Andi. Zlasti v Argentini so prav Andi tisti, ki sploh omogočajo vinogradništvo v suhih in vročih prostranstvih, saj se od tam stekajo velike količine vode, ki jo s pridom uporabljajo za namakanje vinogradov (slika 5.2). Čile na drugi strani za marsikaterega evropskega obiskovalca v kulturnem pogledu deluje precej domače, je pa njegova geografska izolacija privedla do nekaterih unikatnih posebnosti - 


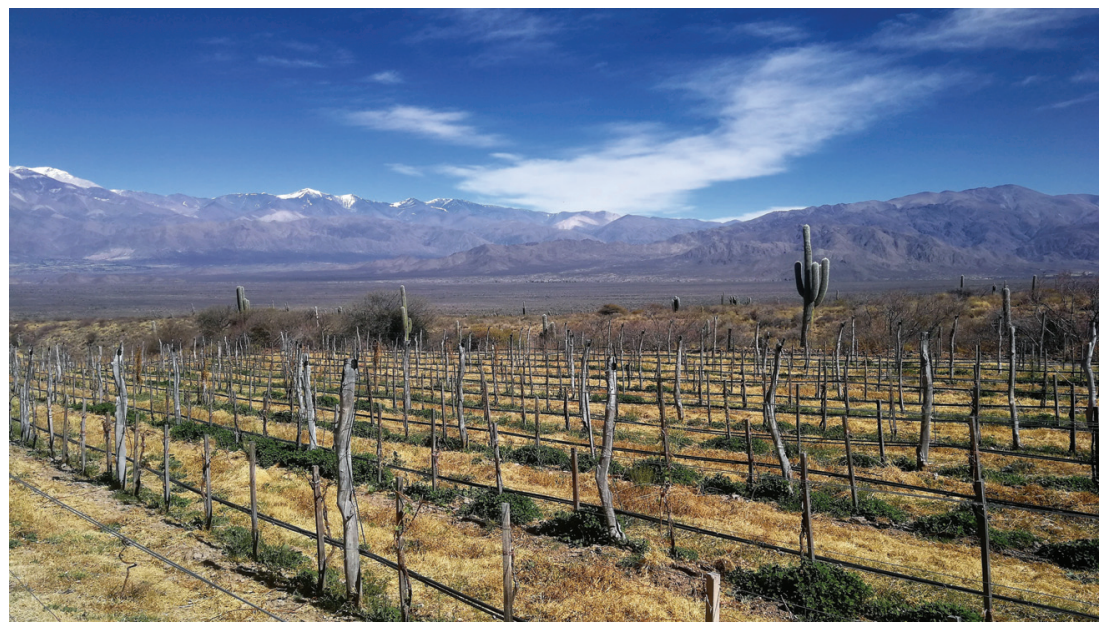

Slika 5.2 Med trtami in kaktusi: vinski turizem 3.0oo m nad morjem - vinograd Altura Maxima, posest Colome, Valle Calchaqui, Argentina, 2018 (foto Simon Kerma)

in vinska trta pri tem ni izjema. Tako v Argentini kot v Čilu je vinski turizem v razcvetu. Med njunimi vinskimi destinacijami močno izstopata Mendoza in Valparaiso z dolino Casablanca, ki sta tudi del prestižne mreže Great Wine Capitals (Kerma, 2018).

\section{Vinski turizem v Sloveniji}

Vinski turizem na Slovenskem ima relativno kratko zgodovino, ki sega v začetek 9o-ih let prejšnjega stoletja, ko sta Turistična zveza Slovenije in Zveza društev vinogradnikov in vinarjev Slovenije leta 1992 začeli promovirati vinogradniško-vinarski turizem. K sodelovanju je bil povabljen širok spekter deležnikov (ministrstva in njihovi organi, Poslovna skupnost za vinogradništvo in vinarstvo, društva vinogradnikov in vinarjev, turistična društva, kmetijske svetovalne službe, občine, potovalne agencije, šole, gostinci, trgovci, krajevne skupnosti, društva in aktivi kmečkih žena). Razvoj podeželja in razvoj vinskoturističnih cest (VTC) kot del vinogradniško-vinskega turizma se je začel izvajati kot nacionalni projekt Ministrstva za kmetijstvo, gozdarstvo in prehrano Rs, z zasnovo 20 vinskih cest (Bojnec in Korpar, 2005, str. 196).

Po zadnjem »Zakonu o vinu« (2006) je vinorodna Slovenija razdeljena na 3 vinorodne dežele in 9 vinorodnih okolišev: (1) vinorodna dežela Podravje (vinorodni okoliš Prekmurje, vinorodni okoliš Šta- 


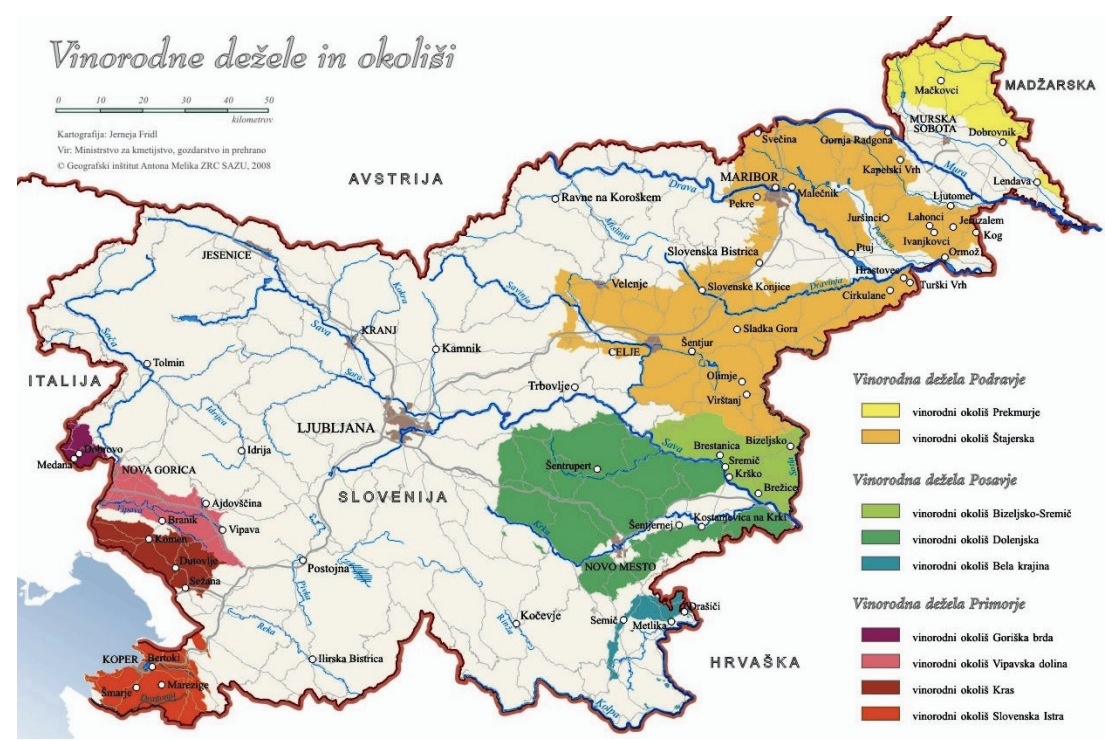

Slika 5.3 Vinorodne dežele in okoliši po zadnjem »Zakonu o vinu« (2006)

jerska), (2) vinorodna dežela Posavje (vinorodni okoliš Bizeljsko Sremič, vinorodni okoliš Dolenjska, vinorodni okoliš Bela krajina) in (3) vinorodna dežela Primorje (vinorodni okoliš Goriška Brda, vinorodni okoliš Vipavska dolina, vinorodni okoliš Kras, vinorodni okoliš Slovenska Istra) (slika 5.3).

$\mathrm{Z}$ vidika razvoja vinskega turizma je najmanjša razvojna enota $\mathrm{z}$ lastno prepoznavno identiteto vinorodni okoliš, najbolj strateška razvojna enota pa vinorodna dežela. Njuna konkurenčnost je odvisna od mednarodne prepoznavnosti Slovenije kot vinorodne dežele in države z več kot 2.500-letno tradicijo kulture vina.

Med proizvode vinskega turizma s številnimi učinki sodijo: vinskoturistične ceste, organizirani izleti in bivanje v vinorodnih deželah, enološka izobraževanja, obiski vinskih kleti, vinski muzeji, prazniki in festivali na temo vina, strokovne prireditve, degustacije vina, lokalni sejmi in akcijska prodaja vin (Mănilă, 2012, str. 56). Na Slovenskem so ponudniki vinskega turizma predvsem gostinci, turistične kmetije in vinske kleti. Med prednostmi vinskega turizma za vinarje sta povečanje neposrednih stikov potrošnikov z vinom in možnost pokušanja vin. Vinarjem obiskovanje vinskih kleti pomeni cenovno ugoden način promocije in trženja vina brez dodatno vloženega časa (Bojnec in Korpar, 2005, str. 191). 
V zadnjem desetletju smo sicer priča izjemnemu razmahu vinskih in kulinaričnih prireditev ter festivalov, a v širšem evropskem kontekstu močno zaostajamo na področju investicij v vinskoturistično infrastrukturo, kot so tematski ali butični vinski hoteli in resorti, sodobne vinske kleti $\mathrm{z}$ degustacijskimi prostori, komunikativni vinski muzeji, galerije in razstave. Programsko nedorečene pa so tudi VTC in druge tematske poti. Ob tem moramo izpostaviti še izrazit vizionarski manko nacionalne politike na področju sistematičnega usmerjanja razvoja vinskega turizma kot tudi organiziranosti in generične promocije slovenskih vinarjev, kulture vina in vinskega turizma kot presečišča med kmetijskim, gospodarskim in kulturnim sektorjem. Kreiranje celostne razvojne vizije in strategije ter interdisciplinarno in medresorsko povezovanje ostajata velika neizkoriščena deviza za dvig mednarodne konkurenčnosti in prepoznavnosti vinskega turizma na Slovenskem (Gačnik, 2014b).

Med strateškimi področji $v$ trženju gastronomskega turizma na Slovenskem so izpostavljene tudi vinske kleti, vinske ceste in drugi gostinski objekti ob vinskih cestah, med predlaganimi doživetji pa degustacije v vinski kleti, piknik v naravi, trgatev, vinski spa idr. Med glavnimi gastronomskimi produkti so izpostavljene tudi vinske kleti, ki ustvarjajo skoraj največjo prepoznavnost gastronomskega turizma na Slovenskem (takoj za vrhunskimi restavracijami) in tudi največje prihodke med vsemi (Slovenska turistična organizacija, 2018, str. 33).

In zakaj na Slovenskem staviti na vinski turizem? Zaradi večje mednarodne prepoznavnosti Slovenije kot vinorodne destinacije $\mathrm{z}$ bogato vinogradniško in vinarsko dediščino ter kulturo vina, večje dodane vrednosti in zaslužka na kmetijah in pri drugih $\mathrm{z}$ vinskim turizmom povezanih deležnikih, tudi v mestih, zaradi ohranjanja kulturne krajine ter snovne in nesnovne kulturne dediščine kot strateškega temelja za razvoj vinskega turizma, zaradi večje privlačnosti podeželja in novih zaposlitvenih priložnosti (Gačnik, 2019).

\section{Vinskoturistična infrastruktura}

Carlsen in Charters (2006, str. 8) poleg t. i. »trde« infrastrukture izpostavljata velik pomen $»$ mehke« infrastrukture za potrebe vinskega turizma, pri čemer navajata znanje, komunikacijska orodja in informacije, mreženje, inovacije in strategije. Gotovo pa so vinske kleti $\mathrm{z}$ degustacijskimi prostori, ustreznim dostopom in urejeno okolico 
tisti element vinskoturistične infrastrukture, na katerega najprej pomislimo. Tu so še vinoteke, vinski bari, restavracije, gostilne, vinski muzeji, oljarne, trgovinice z lokalnimi izdelki, umetniške galerije, avtentične prireditve in festivali, elementi kulturne dediščine in naravne vrednote - vse to so, poleg dodatne lokalno ali regionalno specifične turistične ponudbe, tudi ključni elementi za vzpostavitev in delovanje vinskih turističnih cest.

Ko pomislimo na vinski turizem (velja tudi za definicije), je navadno prva asociacija obisk vinskih kleti, ki so v raziskovalnem smislu tudi idealen prostor opazovanja vinskih turistov. Seveda vinske kleti niso in tudi ne morejo biti edine relevantne za preučevanje izkušenj vinskih turistov. Le celoten vinorodni okoliš ali vinskoturistična regija namreč lahko predstavlja okvir udejstvovanja vinskih turistov (Carlsen in Charters, 2006, str. 9). So pa vinske kleti temeljno izhodišče, saj ponujajo dober vpogled za diagnostiko stanja na terenu. Za usmeritev $\mathrm{v}$ vinski turizem se ne odločajo le male, butične vinske kleti, ampak tudi velike, tako v svetu kot pri nas.

Razvoj vinskega turizma pa je, kot zapisano, odvisen tudi od t. i. mehke vinskoturistične infrastrukture, med katero lahko uvrščamo nesnovno dediščino vinogradništva in vinarstva ter kulturo vina $\mathrm{v}$ najširšem pomenu besede. Ta se kaže skozi naš vsakdanji in praznični način življenja in kulturo, ki je zaznamovala naš odnos do vinske trte in vina. Med vinskimi prazniki, ki se razvijajo tudi v pomembne vinskoturistične prireditve, moramo $\mathrm{v}$ prvi vrsti izpostaviti martinovanja, postavljanja klopotcev pa tudi z vinsko trto in vinom povezane najpomembnejše svetnike (sv. Martin, sv. Urban, Štefanovo, Vincekovo idr.), med vinogradniškimi opravili s turističnim potencialom pa predvsem trgatve.

\section{Vinske kleti in vinski hoteli}

Stopnja razvitosti vinorodnega okoliša ali vinorodne dežele, kot tudi atraktivnost vinskih destinacij, se kaže tudi v specializirani vinskoturistični infrastrukturi, kamor sodi tako tradicionalna kot sodobna arhitektura vinskih kleti. V številnih vinorodnih regijah sveta sodi prva med identitetne temelje, med elemente geografskokulturne prepoznavnosti in ikonične znamenitosti, z avtorskim pečatom svetovno znanih arhitektov. Tovrstna arhitektura sodi med glavne turistične atrakcije, ki niso zanimive le za segment vinskih turistov, ampak za najširši krog turistov, ki obiščejo določene destinacije. Na področju 
nastanitvenih obratov v vinorodnih deželah Slovenije za sosednjimi državami (Avstrija, Madžarska, Hrvaška idr.) zaostajamo po ekskluzivnejši ponudbi, saj pri nas še ne obstajajo manjši, butični, specializirani vinski hoteli, ki postajajo pomemben generator razvoja vinskega turizma v posameznih krajih, okoliših, vinorodnih deželah. S svojimi programi, ponudbo in storitvami kažejo na to, kako misliti kulturo vina v turizmu na najcelovitejši, najkreativnejši in najinovativnejši način. Na Slovenskem imamo nekaj ponudnikov butičnih nastanitev v obliki apartmajev ali sob, med drugim tudi na vinogradniških turističnih kmetijah.

\section{Vinsko turistične ceste in poti}

Kot najpomembnejšo časovno prelomnico pri razvoju vTc moramo izpostaviti leto 1993. Pod okriljem takratnega ministrstva za kmetijstvo je bil zasnovan in izpeljan nacionalni projekt vTc, ki je vinorodno Slovenijo prepletel $\mathrm{z}$ dvajsetimi vinskoturističnimi cestami v vseh vinorodnih deželah, v skupni dolžini več kot $900 \mathrm{~km}$. Leta 2000 je bil projekt podprt z bogatim katalogom vTc, ki naj bi postale glavni razvojni/turistični produkt slovenskega podeželja. V vseh razvitih vinorodnih destinacijah so vTC ali vinske poti temelj oz. hrbtenica razvoja vinskega turizma, ključni dejavnik regionalnega razvoja in razvoja podeželja v vinorodnih regijah. Preko vinskoturističnih cest se ne prodaja le vina in druge "vinske ponudbe« destinacij, ampak celotne regije v najširšem pomenu te besede.

Pomen vTc je večplasten, saj gre za projekt, ki ima različne razsežnosti in učinke. Vplivajo na trajnostni razvoj vinogradništva in vinarstva ter vinskega turizma, in sicer kot dopolnilna dejavnost na manjših kmetijah, kar slednjim lahko pomaga, da ne propadejo. Pomeni torej potencialni vir dodatnega zaslužka. Urejeni in obdelani vinogradi pripomorejo, da se ohranja kultivirana, obdelana pokrajina, da se ta ne zarašča. Posamezni vinorodni kraji ali kar ves vinorodni okoliš se s pomočjo vTC promovirajo kot gospodarsko in kulturno zanimiv prostor z lastno identiteto. To omogoča prodajo pridelkov in izdelkov doma in s pomočjo zadovoljnih obiskovalcev tudi promocijo navzven. Bojnec in K. Korpar (2005, str. 197) izpostavljata, da je pri vinski cesti vino pojmovano kot kulturna dobrina in ne le kot kmetijski pridelek.

Razvoj vinskega turizma v Sloveniji je že več kot dvajset let povezan prav z boljšim ali s slabšim delovanjem vTc, ki naj bi pred- 
stavljale hrbtenico razvoja (vinskega) turizma na podeželju (Kerma, 2012). Pri tem morajo biti upoštevana nekatera dodatna merila in pogoji, med katerimi je najpomembnejši vinorodna pokrajina, saj naj bi vinska cesta potekala samo po vinorodnem območju. Vinorodna pokrajina je geografska regija, kjer vinogradi predstavljajo vsaj $10 \%$ zemljišč, kjer so prisotni elementi vinogradniške kulture in so vinogradi pomemben element krajinske slike. Vinska cesta je turistična pot, speljana po vinorodnem območju, ki povezuje vinotoče, kmetije, ki se ukvarjajo z gostinsko in turistično dejavnostjo, ter naravne in kulturno-zgodovinske znamenitosti območja. Namen vinske ceste je spodbujanje gospodarskega in družbenega razvoja vinorodnega podeželja ter njegovo turistično, kulturno in gospodarsko uveljavljanje (Bojnec in Korpar, 2005, str. 194-195).

Terčelj (2007, str. 142) ugotavlja, da mora vTC izpolnjevati določene pogoje: imeti mora organizirane informacijske točke $\mathrm{z}$ vsemi podatki o ponudbi, imeti mora podrobno geografsko karto vinske ceste $\mathrm{z}$ vrisanimi potmi, gostinskimi objekti in turističnimi znamenitostmi, nuditi mora organizirane izlete in oglede kulturnih znamenitosti, vodene pokušine vina in strokovna predavanja, imeti mora dobro organizirano informacijsko službo ter poskrbeti za aktivno povezovanje vinogradnikov, občin in vlade.

Predstavljeni hipotetični model R. Tomljenović in Getza (2009, str. 47) je lahko uporaben tudi za analizo stopnje razvitosti vinskega turizma na vTC v Sloveniji. Raziskava iz leta 2015 pokaže, da je med dvajsetimi vTc le pet funkcionalno delujočih, ki imajo torej svoj projektni svet, skrbnika, lastne spletne strani, vzpostavljeno mrežo ponudnikov itn. (Tonejec, 2015). To je precej zaskrbljujoče, saj se razmere vse do danes niso bistveno spremenile. Vinske ceste pri nas so še vedno $\mathrm{v}$ iskanju institucionalne podpore in nikakor ne uspejo realizirati svojih razvojnih potencialov (Slovenska turistična organizacija in Ministrstvo za gospodarski razvoj in tehnologijo Republike Slovenije, 2018, str. 21).

\section{Vinski muzeji, galerije in razstave}

Kljub osredotočenosti na vino pa je vinski turizem lahko tudi orodje, s katerim destinacije tržijo vse svoje ostale znamenitosti, zgodovino ter tradicijo (Bojnec in Korpar, 2005), saj je kultura vina najtesneje povezana $\mathrm{z}$ dediščino vina, $\mathrm{z}$ identiteto vinorodnega okoliša, $\mathrm{s}$ kulturološkim terroirjem oz. z njegovo identitetno komponento. Stop- 
nja razvitosti vinskega turizma se ne kaže samo skozi vrhunskost in kakovost vin, ampak tudi v tem, kako vinorodne destinacije komunicirajo svojo lastno identiteto, tudi v obliki specializiranih muzejev, galerij in razstav, ki so povezani s snovno in nesnovno dediščino vinogradništva in vinarstva, s kulturo vina.

Ker sta vinogradništvo in vinarstvo aktivna dediščina in ker sta marsikje pomembni in ponekod celo glavni gospodarski panogi, imajo vinske zbirke in muzeji ob spomeniški, varstveni in didaktični tudi turistično, simbolno in trženjsko vrednost (Gačnik, 1991). $\mathrm{V}$ primeru prekomerne komercialne rabe muzejev lahko posledično prihaja do izgube avtentičnosti ter možnosti folklorizacije dediščine vina, kar na turistični imidž regije deluje negativno (Hall idr., 200o).

$\mathrm{Na}$ Slovenskem nimamo specializiranega nacionalnega muzeja, galerije, zbirke, kjer bi bila celovito predstavljena kultura vina ali njeni posamezni fenomeni. Če z vidika razvoja vinskega turizma prepoznavamo vinorodne dežele kot strateško razvojno jedro, potem moramo tudi v kontekstu njihove muzealizacije razmišljati enako. Gačnik že v času razvoja sodobne muzeologije sredi 9o-ih let prejšnjega stoletja opozori, da etnologi in muzealci potrebujejo natančno izdelan sistem ter mrežo, ki bo pripomogla k ohranjanju lokalnoregionalnih vinoloških dediščin (Gačnik, 1996, str. 426), pri čemer moramo izhajati iz holističnega interdisciplinarnega pristopa v raziskovanju možnih teoretičnih in praktičnih razmerij med človekom (ljudmi) in vinom (Gačnik, 1992, str. 37). Do sedaj edini celostni tovrstni muzejski projekt je bil izpeljan na razstavi Slovenskega etnografskega muzeja "Spet trte so rodile ...: O kulturi vina na Slovenskem" leta 2008, ki je nastala na osnovi monografije Kultura vina na Slovenskem (Terčelj, 2007).

\section{Vinska praznovanja, prireditve in festivali}

V definicijah in opredelitvah vinskega turizma sodi obiskovanje vinskih prireditev in festivalov, ob obiskovanju vinogradov in vinskih kleti v izbranih vinskih regijah, med glavne stebre vinskega turizma. V Evropi moramo ta razvoj graditi na stoletni dediščini vinogradništva in vinarstva ter kulturi vina, v povezavi s sodobno kreativnostjo in inovativnostjo. Terčelj (2007) je zapisal, da je kultura pitja povezana s kulturo naroda, pridelovanjem, trženjem in samim pitjem. Zato se v različnih vinorodnih okoljih oblikujejo različne kulture uživanja vina. 
$Z$ vinom povezani prazniki in praznovanja ter vinske prireditve in festivali so nepogrešljiv medij pri komuniciranju kulture vina in vinskega turizma, ne le na Slovenskem, ampak povsod po svetu. Predstavljajo t. i. mehko vinsko turistično infrastrukturo, ki je pomembna za nacionalno in mednarodno prepoznavnost vin, vinarjev, vinskih kleti, vinorodnih okolišev in vinorodnih dežel ter vinskoturističnih destinacij (Gačnik, 2015).

Bogastvo različnih vinskih kultur naj se odraža tudi v bogastvu vinskih in kulinaričnih prireditev in festivalov na Slovenskem, kjer lahko prepoznamo deset različnih tipov, usmerjenih v specializirano in segmentirano predstavljanje kulture vina in vinskih posebnosti (Gačnik, 2014a; 2019):

1. posamezno vinsko sorto (traminec, refošk ...),

2. poseben tip/zvrst vina (oranžna vina, penine ...),

3. izbrano vino in tradicionalne kmetijske izdelke/pridelke (pršut in teran ...),

4. vino v kontekstu kompleksnih gastronomskih prireditev (VinDel...),

5. izbran kraj, vinski okoliš ali vinsko regijo (Salon Jeruzalem ...),

6. vino $v$ povezavi $z$ umetnostjo (Dnevi poezije in vina ...),

7. izobraževalne in družabne prireditve (študentski festival Vino ni voda na Ptuju ...),

8. rekreativne prireditve (nordijska hoja v Svečini ...),

9. izbore za vinske kraljice (nacionalne, regijske, lokalne, izbrane vinske sorte),

10. novodobne prireditve, ki temeljijo na dediščini vinogradništva in vinarstva (postavljanje klopotcev, martinovanja ...)

Nekateri v ospredje postavljajo vino (spoznavanje vina), drugi življenjski slog (druženje ob vinu). Oba koncepta sta seveda legitimna in potrebna z vidika razvoja vinskega turizma in vinske kulture, skozi katero se zrcalijo naš odnos do vinske trte in vina, naš način življenja in identiteta naroda. V njima se kaže ne le spoštovanje bogate dediščine vinogradništva in vinarstva, ampak tudi naša odprtost do novega, do mode in globalnih trendov.

\section{Vinskoturistične atrakcije}

Kljub osredotočenosti na vino je vinski turizem orodje, s katerim destinacije tržijo tudi vse svoje ostale znamenitosti, zgodovino ter tra- 
dicijo (Bojnec in Korpar, 2005). Vinskoturistične atrakcije so najtesneje povezane $\mathrm{z}$ interpretacijo tradicije in s sodobno identiteto naroda. Vse to se odraža v kreativnosti in inovativnosti pri osmišljanju raritet in atrakcij na področju vinskega turizma; slednje tako ne temeljijo le na izpostavljanju avtohtonih oz. udomačenih vin, na raznolikosti vinogradniških krajin, ampak tudi na inovativnem razumevanju dediščine in kulture vina v sodobnem času.

Gačnik (2014a) izpostavlja šest atrakcij na področju vinskega turizma pri nas:

1. nacionalno himno (Prešernova Zdravljica časti vinsko trto in nje sadove ter povezuje evropske narode),

2. najstarejšo trto na svetu (slika 5.4) z več kot 450-letno zgodovino (postati bi morala t. i. "nulta točka« oz. mednarodna ikona vinskega turizma),

3. klopotec kot transregionalni simbol vinorodnih krajev,

4. dediščino steklarstva na Slovenskem s skoraj 350-letno tradicijo,

5. vinski festivalski »bum« (ki Slovenijo uvršča med najbolj festivalske države v Evropi),

6. največje vinsko kraljestvo na svetu (ob nacionalni vinski kraljici tudi regijske in lokalne vinske kraljice, vinske kraljice posameznih vinskih sort pa tudi vinska princesa in dva vinska kralja posameznih vinskih sort),

7. nogometno vinsko reprezentanco Slovenije.

Kot novodobno sedmo potencialno vinsko turistično atrakcijo lahko dodamo tudi fenomen vinskih fontan (Marezige v Slovenski Istri, Vodole na Štajerskem in Šmarjeta na Dolenjskem), pri čemer moramo ohraniti kritični odnos do tovrstnih pojavov. Nekatere vinskoturistične atrakcije lahko razumemo kot svojevrstne paradokse na področju vinskega turizma (Gačnik in Kerma, 2013; Kerma in Gačnik, 2015) in kot priložnosti za pripovedovanje zgodb o kulturi vina na Slovenskem.

\section{Zaključek - trendi in razvojne priložnosti}

Za Slovenijo kot vinorodno deželo pomeni usmeritev v razvoj vinskega (in gastronomskega) turizma eno od ključnih strateških razvojnih usmeritev in prioritet (Gačnik, 2014b). Tega se zavedajo v 


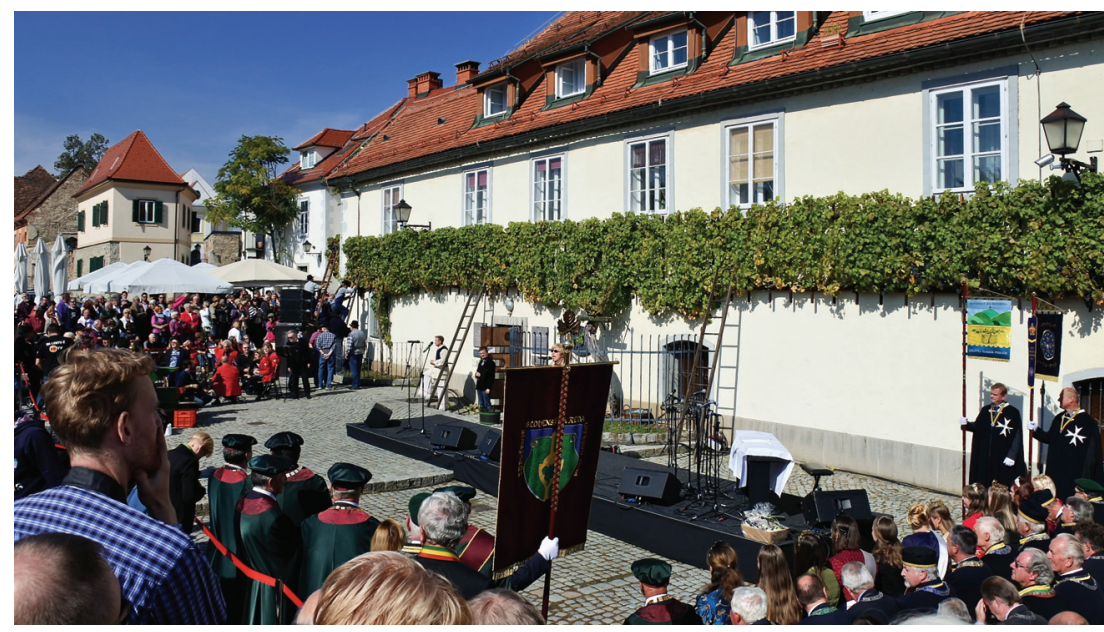

Slika 5.4 Stara trta na mariborskem Lentu - ikonična znamenitost ter ena glavnih atrakcij na področju vinskega turizma na Slovenskem; slavnostna trgatev, 2015 (foto Aleš Gačnik)

številnih evropskih vinorodnih regijah, kjer sta razumevanje in razvoj vinskega turizma odvisna od celostnega interdisciplinarnega raziskovalnega in razvojnega pristopa, še zlasti pa od nujnega medsektorskega povezovanja in sodelovanja. Vinski turizem, kot presek kmetijstva (vinogradništva in vinarstva), turizma (gostinstva, hotelirstva, gastronomije), kulture (dediščine, umetnosti in oblikovanja) ter znanosti in izobraževanja, je lokalni fenomen, ki se trži globalno.

Med neizkoriščenimi potenciali lahko izpostavimo še tesnejše povezovanje $\mathrm{z}$ mednarodnimi organizacijami in projekti, kot so UNEsco, EnoTourism Academy (Global Wine Tourism Organisation), IGCAT (Institut of Gastronomy, Culture, Art \& Tourism), Iwinetc (International Wine Tourism Organisation), Great Wine Capitals idr., kot tudi vključevanje $\mathrm{v}$ projekte evropskih kulturnih poti. Na nacionalni ravni smo priča večdesetletnemu manku nacionalne strategije razvoja vinskega turizma, zato smo kot država izpostavljeni bolj ali manj stihijskemu, nestrateškemu in neuravnoteženemu razvoju vinskoturističnega sektorja.

Vrhunsko vino samo po sebi še ne zagotavlja kakovosti in uspeha $\mathrm{v}$ vinskem turizmu (Gačnik, 2019), zato lahko med trendi na področju razvoja vinskega turizma izpostavimo:

- umeritev v trajnostno, zeleno, butično, lokalno, odgovorno, 
- usmeritev v ekološko vinogradništvo, vinarstvo in vinski turizem,

- izpostavljanje avtohtonih in udomačenih vinskih sort,

- nadgradnjo filozofije od grozdja do vina, ki se ne sme končati pri ustvarjanju storitev, ampak v kreiranju vinskoturističnih doživetij,

- avtentično ponudbo in dovolj udobja,

- povezovanje vinskega turizma z rekreacijo,

- povezovanje vinskih prireditev in festivalov z različnimi zvrstmi umetnosti,

- drzno sodobno vinsko arhitekturo, inspirirano z identiteto lokalnega okolja,

- razvoj vinskih hotelov in butičnih namestitev,

- razvoj tematskih vinskih muzejev/galerij/zbirk.

Reinvencija tradicije, izpostavljanje lokalnih posebnosti, poudarjanje starih sort vinske trte in "nekdanjih" postopkov pridelave vina ter omenjena institucionalna zaščita sort in vin ter drugih identifikatorjev vinogradniško-vinske kulture so instrumenti, ki poudarjajo avtentičnost in posebnost neke vinske regije kot turistične destinacije (Kerma, 2018). Zaostrene razmere na globalnem vinskem trgu usmerjajo preplet vinarskega in turističnega gospodarstva v skupne aktivnosti. Pogosto in vedno bolj se omenjeni panogi vzajemno dopolnjujeta in prihaja do sinergijskih učinkov, ki se kažejo v razcvetu številnih vinskoturističnih destinacij sveta. Nakazali smo izjemen potencial za razcvet vinskega turizma tudi pri nas. Vinorodna in vinoljubna Slovenija ima za to vse ključne predispozicije.

\section{Literatura}

Bojnec, Š., in Korpar, K. (2005). Vino in turizem v Ljutomersko-Ormoških goricah. V S. Kavčič (ur.), Slovenija $v$ EU - izzivi za kmetijstvo, živilstvo in podeželje: 3. konferenca DAEs, Moravske Toplice, 10-11. november 2005 (str. 191-201). Društvo agrarnih ekonomistov Slovenije.

Bojnec, Š., Jurinčič, I., in Tomljenović. R. (2007). Marketing of wine tourism as a teritorial product. V Managing global transitions: globalisation, localisation, regionalisation (str. 1075-1082). Faculty of Management.

Byrd, E. T., Canziani, B., Hsieh, Y.-C., Debbage, K., in Sonmez, S. (2016). Wine tourism: Motivating visitors through core and supplementary services. Tourism Management, 52, 19-29. 
Carlsen, J., in Charters, S. (ur.). (2006). Global wine tourism: Research, management and marketing. САв Publishing.

Charters, S. (2009). New World and Mediterranean wine tourism: A comparative analysis. Tourism, 57(4), 369-379.

Charters, S. (2012). The myths of wine tourism in Europe. V M. F. Romano in M. Natilli (ur.), Wine and food tourism: First European conference (str. 19-42). Edizioni ETs.

D’Alessio, O., in Santini, M. (2006). Vodnik po evropskih vinogradih. Cankarjeva založba.

Gačnik, A. (1991). Vino in muzej: Ptujski muzej včeraj in jutri (ker danes ga ni). Argo: časopis slovenskih muzejev, 31/32, 60-62.

Gačnik, A. (1992). Vinogradniška zbirka Belokranjskega muzeja v Metliki: prispevek k zgodovini »etno-muzeološke« kritike. Glasnik Slovenskega etnološkega društva, 32(1/2), 35-40.

Gačnik, A. (1996). Muzejska razstava med etnologijo in etnološko muzeologijo: "vinarske podobe « med etnografskim preteklikom in muzejskim sedanjikom. Etnolog: glasnik Slovenskega etnografskega muzeja, 6(1), 418-426.

Gačnik, A. (2014a). Slovenian wine stories and wine identities: From heritage and culture of wine to wine tourism. V M. Harvey, W. Frost in L. White (ur.), Wine and identity: Branding, heritage, terroir (str. 57-70). Routledge.

Gačnik, A. (2014b). Vinski in gastronomski turizem, strateška razvojna priložnost Slovenije. Vinsko kulinarični trendi, 23-25.

Gačnik, A. (2015). Vindel med lokalnim in globalnim, vinske prireditve in festival vina na Slovenskem. Vinsko kulinarični trendi, 16-19.

Gačnik, A. (2016). Profil vinskih turistov in obiskovalcev vinskih festivalov. Vinsko kulinarični trendi, 17-19.

Gačnik, A. (2019). Vinski turizem na Slovenskem: stanje in perspektive. Vinsko kulinarični trendi, 8-10.

Gačnik, A., in Kerma, S. (2013). Paradoksi vinskega turizma na Slovenskem: izbrani primeri [predstavitev na konferenci]. Turizem, izobraževanje in management, Portorož, Slovenija.

Getz, D. (2000). Explore wine tourism: Management, development \& destinations. Cognizant Communication.

Getz, D., in Brown, G. (2006). Critical success factors for wine tourism regions: A demand analysis. Tourism Management, 27(1), 146-158.

Hall, C. M., in Macionis, N. (1998). Wine tourism in Australia and New Zealand. V R. Butler, M. Hall in J. Jenkins (ur.), Tourism and recreation in rural areas (197-224). Wiley.

Hall, C. M., Sharples, L., Cambourne, B., in Macionis N. (2000). Wine tourism around the world. Butterworth Heinemann.

Johnson, R., in Bruwer, J. (2007). Regional brand image and percieved wi- 
ne quality: The consumer perspective. International Journal of Wine Business Research, 19(4), 276-297.

Jurinčič, I., in Bojnec, Š. (2009). Wine tourism development: The case of wine district in Slovenia. Tourism, 57(4), 435-448.

Kerma, S. (2012). Wine tourism as a factor of regional development: The case of Primorska wine region, Slovenia. V M. F. Romano in M. Natilli (ur.), Wine and food tourism: First European conference (str. 237254). Edizioni ETs.

Kerma, S. (2014). Geografski prispevek k raziskovanju vinskega turizma. V D. Cigale idr. (ur.), Geografsko raziskovanje turizma in rekreacije v Sloveniji (str. 89-102). Znanstvena založba Filozofske fakultete.

Kerma, S. (2018). Vinski turizem z geografskim poreklom. Založba Univerze na Primorskem.

Kerma, S., in Gačnik, A. (2015). Wine tourism as an opportunity for tourism development: Examples of good practice in Slovenia. Journal of International Food \& Agribusiness Marketing, 27(4), 311-323.

Lapsley, J., in Moulton, K. (2001). Successful wine marketing. Aspen Publishers.

Mănilă, M. (2012). Wine tourism - A great tourism offer face to new challenges. Journal of Tourism, 13, 54-60.

Quadri-Felitti, D., in Fiore, A. M. (2016). Wine tourism suppliers' and visitors' experiential priorities. International Journal of Contemporary Hospitality Management, 28(2), 397-417.

Remaud, H., in Lockshin, L. (2009). Building brand salience for commodity-based wine regions. International Journal of Wine Business Research, 2(1), 79-92.

Robinson, J. B. 1. Austria. https://www.jancisrobinson.com/learn/wineregions/austria

Ross, G. F. (1994). The psychology of tourism (Australian Studies in Tourism No. 1). Hospitality Press.

Slovenska turistična organizacija. (2018). Okusiti Slovenijo: akcijski načrt razvoja in trženja slovenske gastronomije 2019-2023 [brošura]. https://www.slovenia.info/uploads/gastronomija_b2b/ang_slo _lowres.pdf

Slovenska turistična organizacija in Ministrstvo za gospodarski razvoj in tehnologijo Republike Slovenije. (2018). Okusiti Slovenijo: kandidatura Slovenije za Evropsko gastronomsko regijo 2021 [brošura]. https://www.slovenia.info/uploads/publikacije/taste_slovenia/ okusiti-slovenijo.pdf

Terčelj, D. (2007). Kultura vina na Slovenskem. Tovarna tradicij.

The Vignobles \& Découvertes label. (2020, 28. maj). Explore France. https://uk.france.fr/en/news/article/vignobles-et-decouvertes

Tomljenović, R., in Getz, D. (2009). Life-cycle stages in wine tourism de- 
velopment: A comparison of wine regions in Croatia. Tourism Review International, 13(1), 31-49.

Tonejec, A. (2015). Razvitost vinskega turizma $v$ Sloveniji [neobjavljena diplomska naloga]. Univerza na Primorskem.

Vaudour, E. (2002). The quality of grapes and wine in relation to geography: Notions of terroir at various scales. Journal of Wine Rese$\operatorname{arch}, 13(2), 117-141$.

Vo Thanh, T., in Kirova, V. (2018). Wine tourism experience: A netnography study. Journal of Business Research, 83, 30-37.

Wade, R. I., Pinto, C., Jacobs, H., in Martin, D. (2006). Wine tourism: Motivations of winery visitation in the niagara wine region. V P. Tsarta, E. Christou in M. Sigala (ur.), In search of excellence for tomorrow's tourism, travel and hospitality: Proceedings, 24th Eurochrie Congress, Thessaloniki, Greece, 25-28 October 2006. The University of the Aegean.

Zakonu o vinu (zvin). (2006). Uradni list Republike Slovenije, (105). https://www.uradni-list.si/1/objava.jsp?sop=2006-01-4488 